Original Article

\title{
Sorghum hybrids grown in hydroponics contrast for phosphorus use efficiency
}

\author{
Híbridos de sorgo crescidos em hidroponia contrastam para eficiência de uso de fósforo
}

\author{
K. J. Silva ${ }^{\mathrm{a}}$ (1), C. V. Santos ${ }^{\mathrm{b}}$ (D), C. B. Menezes ${ }^{\mathrm{a} *}$ (1) and S. M. de Sousa ${ }^{\mathrm{a}}$ (1) \\ aEmbrapa Milho e Sorgo, Sete Lagoas, MG, Brasil \\ bUniversidade Federal de Viçosa, Viçosa, MG, Brasil
}

\begin{abstract}
Phosphorus (P) use efficiency is crucial for sorghum production. P acquisition efficiency is the most important component of $\mathrm{P}$ use efficiency. The early-stage evaluation of plant development is a useful tool for identifying P-efficient genotypes. This study aimed to identify sorghum hybrids that are efficient in P use efficiency and assess the genetic diversity among hybrids based on traits related to P acquisition efficiency. Thus, 38 sorghum hybrids and two inbred lines (checks) were evaluated under low and high $\mathrm{P}$ in a paper pouch system with nutrient solution. Biomass and root traits related to $\mathrm{P}$ efficiency were measured. There was no interaction between genotypes and $\mathrm{P}$ levels concerning all evaluated traits. The biomass and root traits, except root diameter, presented smaller means under low P than high P. Efficient and inefficient hybrids under each P level were identified. The genetic diversity assessment grouped these genotypes in different clusters. The hybrids AG1090, MSK326, AG1060, 1G100, AS 4639, DKB 540, and DKB 590 were superior under low-P and high-P. Hybrids SC121, 1236020 e 1167017 presented the lowest means than all other hybrids, under both conditions. The evaluated hybrids showed phenotypic diversity for traits related to $\mathrm{P}$ acquisition, such as root length and root surface area, which can be useful for establishing selection strategies for sorghum breeding programs and increasing P use efficiency.
\end{abstract}

Keywords: abiotic stress, phenotyping, genetic variability, root morphology, Sorghum bicolor.

\begin{abstract}
Resumo
A eficiência do uso do fósforo (P) é fundamental para a produção de sorgo. A avaliação no estágio inicial do desenvolvimento da planta é uma ferramenta útil para a identificação de genótipos eficientes de P. Este trabalho teve como objetivo identificar híbridos de sorgo que sejam eficientes ao uso de P e avaliar a diversidade genética entre os híbridos com base em características relacionadas à eficiência de aquisição de P. Assim, 38 híbridos de sorgo e duas linhagens (testemunhas) foram avaliados sob baixo e alto $\mathrm{P}$ em sistema de pastas de papel com solução nutritiva. Características de biomassa e de raiz relacionadas à eficiência de P foram mensuradas. Não houve interação entre genótipos e níveis de P em todas as características avaliadas. As características de biomassa e raiz, exceto o diâmetro da raiz, apresentaram médias menores sob baixo P em comparação com alto P. Híbridos eficientes e ineficientes sob cada nível de $\mathrm{P}$ foram identificados e agrupados quanto à diversidade genética. Os híbridos AG1090, MSK326, AG1060, 1G100, AS 4639, DKB 540 e DKB 590 foram superiores sob baixo-P e alto-P. Os híbridos SC121, 1236020 e 1167017 apresentaram as menores médias que todos os outros híbridos, em ambas condições. Os híbridos avaliados apresentaram diversidade fenotípica para características relacionadas à aquisição de P, como comprimento e área superficial da raiz, o que pode ser útil para estabelecer estratégias de seleção para programas de melhoramento de sorgo e aumentar a eficiência de uso do P.
\end{abstract}

Palavras-chave: estresse abiótico, fenotipagem, variabilidade genética, morfologia radicular, Sorghum bicolor.

\section{Introduction}

Sorghum bicolor is the fifth most-produced cereal in the world and is an important food source for more than half a billion people (FAO, 2020). Forecasting sorghum production for the $2020 / 2021$ harvest is near 60 million tons (USDA, 2020a). Sorghum attracts attention due to its versatility, which extends from human and animal food to raw material for several products (Freitas et al., 2012).
Sorghum is broadly adapted to different environments, including those with poor soil fertility and drought (Weltzien et al., 2006).

Abiotic stresses are a major constraint for agriculture, which includes nutrient deficiencies in soils. Lowphosphorus $(\mathrm{P})$ availability in the soil is one of the most relevant factors limiting sorghum production (López-

*e-mail: sylvia.sousa@embrapa.br; cicero.menezes@embrapa.br

Received: June 9, 2021 - Accepted: November 12, 2021 
Arredondo et al., 2014), especially in tropical weathered soils (Novais and Smyth, 1999). P use eficiency in plants can be achieved by mechanisms underlying both P acquisition and P internal utilization efficiency (Parentoni and SouzaJunior, 2008). P bioavailability is generally greatest in the topsoil and foraging can be improved through several mechanisms, such as production of axial roots, shallower axial root growth angles, greater lateral root density, reduced root metabolic cost, which vary among species and genotypes (Barros et al., 2020; Wen et al., 2019; Magalhães et al., 2017).

In the seedling stage is feasible to differentiate genotypes considering $P$ acquisition efficiency, due to changes in root architecture and morphology under low-P (Sousa et al., 2012; Hufnagel et al., 2014; Bernardino et al., 2020, 2021). The use of appropriate phenotyping methods to analyze seedlings reduces cost and time in the selection of P-efficient genotypes (Van Eeuwijk et al., 2019).

$\mathrm{P}$ acquisition efficiency is not an easy parameter to evaluate in the field but is often related to differences in root morphology (Lynch, 2011). Association mapping in two sorghum diversity panels phenotyped for root system morphology and architecture and P uptake in hydroponics, and grain yield and biomass accumulation under low-P conditions, in Brazil and Mali showed that sorghum PHOSPHORUS-STARVATION TOLERANCE1 (SbPSTOL1) alleles are associated with root diameter, root surface area and enhanced P uptake under low-P (Hufnagel et al., 2014). The authors also showed that root length and surface area were positively correlated with grain yield in the soil, emphasizing the importance of early phenotyping to increase sorghum adaptation to low-P availability. Subsequently, Bernardino et al. (2020) in a multi-trait mapping detected 14 QTLs co-localized with grain yield and/or root morphology under hydroponics with SbPSTOL1.

A better understanding of how sorghum hybrids respond to $\mathrm{P}$ starvation is necessary to breed crops with enhanced P use efficiency traits (Hufnagel et al., 2014; Wen et al., 2019; Bernardino et al., 2020, 2021). Thus, this study aimed to identify and characterize hybrids regarding root traits related to $P$ acquisition efficiency.
A better understanding of how sorghum hybrids respond to P starvation is necessary to breed crops with enhanced P use efficiency traits (Hufnagel et al., 2014; Wen et al., 2019; Bernardino et al., 2020, 2021). Thus, this study aimed to identify and characterize hybrids grown in hydroponics regarding biomass and root traits related to $P$ acquisition efficiency.

\section{Material and methods}

\subsection{Sorghum root system phenotyping}

Thirty-eight grain sorghum hybrids and two inbred lines, SC121 and KAT83369 (checks) were evaluated at the seedling stage for root morphology and biomass traits under low and high P conditions. The traits were assessed in nutrient solution as described in Figure 1 (Sousa et al., 2012; Hufnagel et al., 2014), using a randomized block design with three replicates.

The sorghum seeds were surface-sterilized using $0.5 \%$ sodium hypochlorite for 5 minutes, washed with distilled water, and placed in moistened paper rolls. After four days, uniform seedlings were transferred to moistened blotting papers and placed into paper pouches $(24 \times 33 \times 0.02 \mathrm{~cm})$ (Hund et al., 2009).

Each experimental unit consisted of 10 pouches, with three plants per pouch, whose bottom $(3 \mathrm{~cm})$ was immersed in containers filled with five liters of Magnavaca modified nutrient solution (Magnavaca et al., 1987), with P concentration of $2.5 \mu \mathrm{M}$ (low-P) and $250 \mu \mathrm{M}$ (high-P) under continuous aeration. The nutrient solution was changed every three days and the $\mathrm{pH}$ was maintained at $\mathrm{pH}$ 5.65. The containers were kept in a growth chamber at $27 / 20^{\circ} \mathrm{C}$ day/night temperatures, light intensity of $330 \mu \mathrm{mol}$ photons $\mathrm{m}^{-2} \mathrm{~s}^{-1}$ and 12 -h photoperiod.

After 13 days, root images were captured with a digital photography setup and analyzed using RootReader2D (USDA, 2020b) and WinRHIZO software (Regent Instruments Inc., 2020). The imaging system consists of a Nikon D300s digital SLR Camera with $60 \mathrm{~mm}$ macro lens that was affixed to a
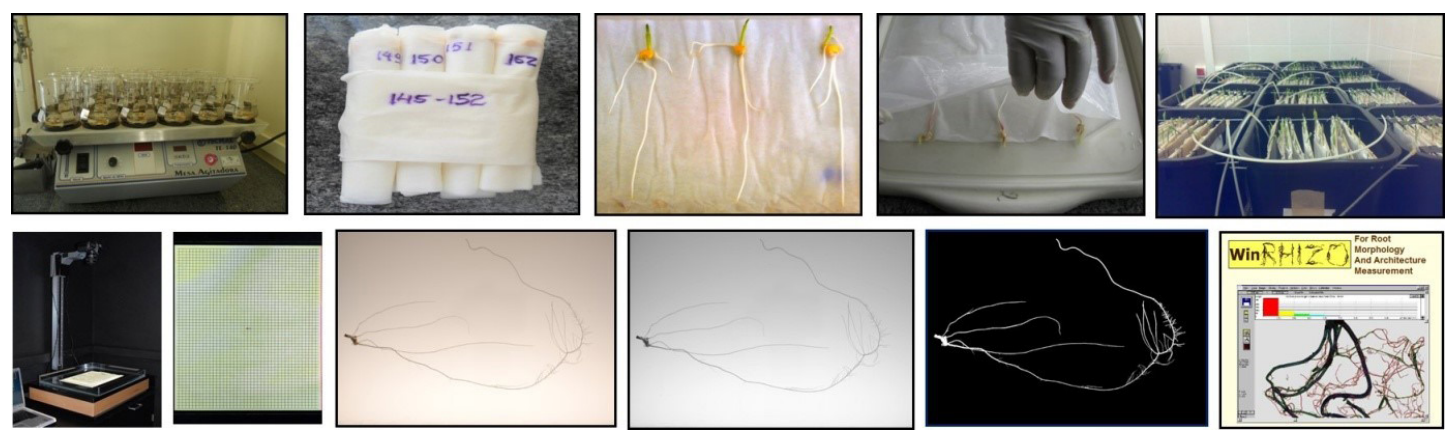

Figure 1. Digital imaging and quantitative analysis of root system morphology in paper pouch system. Seeds were surface-sterilized and placed in moistened paper rolls. After four days, uniform seedlings were transferred to moistened blotting papers and placed into paper pouches with nutrient solution for 13 days. The captured images were batch converted to an 8-bit grayscale format using a custom written Image plugin (NIH, 2020). The images were then batch thresholded using the RootReader2D software. The thresholded images were then imported into the WinRHIZO software for root trait analysis and quantification. The images were analyzed using a calibration grid as a reference scale and changing the input settings to pale roots on a black background. 
copy stand and calibrated to have a fixed focal plane scale of 140 pixels $\mathrm{cm}^{-1}$. The root systems of each plant were spread out in a clear, water filled tray that was illuminated from below and individually imaged. The captured images were batch converted to an 8-bit grayscale format using a custom written Image $(\mathrm{NIH}, 2020)$ plugin. The images were then batch thresholded using the RootReader2D software. During thresholding, the pixel intensities were inverted and the dark roots were separated from the illuminated background using a double adaptive thresholding filter. The settings used for the double adaptive filter were 15 and 65 for the minimum and maximum thresholding values, respectively, and kernel sizes of $21 \times 21$ pixels with thresholding criteria of 0.09 percent or more above the local pixel intensity average for both filter passes. The thresholded images were then imported into the WinRHIZO software for root trait analysis and quantification. The images were analyzed using a calibration grid as a reference scale and changing the input settings to pale roots on a black background (Sousa et al., 2012).

The analyzed traits were root length $(R L)(\mathrm{cm})$, root diameter (RD) (mm), total root surface area (SA) $\left(\mathrm{cm}^{2}\right)$, root volume $(\mathrm{RV})\left(\mathrm{cm}^{3}\right)$, the surface area of roots with diameter between 0 and $1 \mathrm{~mm}$ (SA1), 1 and $2 \mathrm{~mm}$ (SA2) and, $>2$ (SA3) $\left(\mathrm{cm}^{2}\right)$.

The roots and shoots were dried separately at $65{ }^{\circ} \mathrm{C}$ to a constant weight to obtain root and shoot dry weight (RDW and SDW, respectively) (g) and root/shoot ratio (RSR).

\subsection{Statistical analysis}

Traits obtained under low and high $\mathrm{P}$ conditions were subject to individual and joint analysis of variance. The multiple comparison procedure for all genotypes in both P levels were performed according to the Scott and Knott (1974) test at 5\% probability. Data analysis was performed using the software Genes (Cruz, 2013).

Biplots of the principal component analysis PCA were plotted separately for each P level with the traits evaluated. The mean of each trait was standardized to avoid effects due to scaling differences. Graphical plotting was done with the ggplot2 (Wickham, 2016) package of the R software version 3.2.5 (R Core Team, 2016).

Euclidean distance mean matrix was calculated and used as input data for cluster analysis based on the Unweighted Pair-Group Method of Arithmetic Averages (UPGMA) under each P level. The cluster was performed using the package ape (Paradis and Schliep, 2019) and ggtree (Yu et al., 2017). These packages are available in the $\mathrm{R}$ software version 3.2.5 (R CORE TEAM, 2016).

\section{Results}

There was a significant difference $(p<0.01)$ for genotypes for all traits in both $\mathrm{P}$ levels (as shown in Table 1). The coefficient of variation (CV) ranged from 6.18\% (RD) to $18.24 \%$ (RV) at low-P and from 5.16\% (RD) to $19.27 \%$ (RSR) at high-P, indicating good experimental accuracy, except for SA3, which presented CV greater than $40 \%$. All traits presented high heritability, exception for SA3 in both P conditions and RDW and SDW under low-P. Heritability presented the highest values under low-P for RSR (88.2\%), followed by SA1 (83.5\%) and RL (80.8\%). The highest heritability value at high-P was also observed for SA (82.1\%), followed by RV (81.5\%) and RL (81.1\%). The residuals showed normal distribution and homogeneity of variances.

Table 1. Summary of individual analysis of variance of 40 sorghum genotypes grown in nutrient solution with low and high P.

\begin{tabular}{|c|c|c|c|c|c|c|c|c|c|c|c|}
\hline \multirow{2}{*}{ SV } & \multirow{2}{*}{ DF } & \multicolumn{10}{|c|}{ Mean square } \\
\hline & & $\mathbf{R L}$ & SA & RD & RV & SA1 & SA2 & SA3 & RDW & SDW & RSR \\
\hline & & \multicolumn{10}{|c|}{ Low $\mathrm{P}$} \\
\hline Genotype & 39 & $15034.45^{* *}$ & $1224.80^{* *}$ & $0.01^{* *}$ & $0.71^{* *}$ & $452.38^{* *}$ & $180.40^{* *}$ & $7.01^{*}$ & $0.00007^{* *}$ & $0.00003^{* *}$ & $0.18^{* *}$ \\
\hline Block & 2 & 7448.64 & 282.61 & 0.01 & 0.07 & 33.82 & 39.17 & 0.44 & 0.00001 & 0.00001 & 0.18 \\
\hline Error & 78 & 2894.08 & 242.80 & 0.00 & 0.17 & 74.51 & 77.04 & 4.20 & 0.00004 & 0.00002 & 0.02 \\
\hline Mean & & 368.55 & 101.23 & 0.88 & 2.23 & 48.58 & 36.43 & 4.91 & 0.02701 & 0.02346 & 0.91 \\
\hline$h^{2}$ & & 0.81 & 0.80 & 0.62 & 0.77 & 0.84 & 0.57 & 0.40 & 0.40370 & 0.43170 & 0.88 \\
\hline \multirow[t]{2}{*}{ C.V. } & & 14.60 & 15.39 & 6.18 & 18.24 & 17.77 & 24.09 & 41.74 & 23.34188 & 18.06008 & 16.11 \\
\hline & & \multicolumn{10}{|c|}{ High P } \\
\hline Genotype & 39 & $15219.18^{* *}$ & $1237.79^{* *}$ & $0.01^{* *}$ & $0.74^{* *}$ & $413.76^{* *}$ & $207.04^{*}$ & $5.56^{\mathrm{ns}}$ & $0.00008^{* *}$ & $0.00003^{* *}$ & $0.067^{* *}$ \\
\hline Block & 2 & 58122.44 & 6245.93 & 0.01 & 4.08 & 1341.30 & 6.01 & 8.45 & 0.00001 & 0.00000 & 0.00 \\
\hline Error & 78 & 2870.30 & 221.02 & 0.00 & 0.14 & 79.04 & 74.92 & 4.80 & 0.00003 & 0.00001 & 0.03 \\
\hline Mean & & 396.96 & 105.42 & 0.85 & 2.25 & 52.58 & 36.10 & 4.77 & 0.02916 & 0.02341 & 0.83 \\
\hline$h^{2}$ & & 0.81 & 0.82 & 0.72 & 0.81 & 0.81 & 0.64 & 0.14 & 0.60550 & 0.70280 & 0.61 \\
\hline C.V. & & 13.50 & 14.10 & 5.16 & 16.42 & 16.91 & 23.98 & 45.91 & 19.02373 & 13.68129 & 19.26 \\
\hline
\end{tabular}

Source of variation (SV); ${ }^{* *}{ }^{*}$. ns: significant at $1 \% ; 5 \%$ and not significant by the test F respectively. Degrees of freedom (DF); root length (RL - $\mathrm{cm}$ ); root diameter (RD - mm); root volume (RV- $\left.\mathrm{cm}^{3}\right)$; total surface area $\left(\mathrm{SA}-\mathrm{cm}^{2}\right)$; surface area of roots with diameter between 0 and $1 \mathrm{~mm}\left(\mathrm{SA} 1-\mathrm{cm}^{2}\right)$; surface area of roots with diameter between 1 and $2 \mathrm{~mm}\left(\mathrm{SA} 2-\mathrm{cm}^{2}\right)$; surface area roots with diameter $>2 \mathrm{~mm}\left(\mathrm{SA} 3-\mathrm{cm}^{2}\right)$; root-to-shoot ratio $(\mathrm{RSR}-\mathrm{g})$; root dry weight (RDW); shoot dry weight (SDW); heritability $\left(\mathrm{h}^{2}\right)$; coefficient of variation $(\mathrm{CV})$. 
Considering the joint analysis, all traits showed significant differences ( $\mathrm{p} \leq 0.01$ ), concerning the factor genotypes, indicating the existence of genetic variability (as shown in Table 2). The estimated heritability value was low for RD (0.17), and medium or high for the other traits, ranging from $0.45(\mathrm{RV})$ to $0.88(\mathrm{RL})$. Regarding the factor P level, significant differences were verified for all traits, except for RV, SA2, SA3 and SDW, indicating that the root morphology of the genotypes was affected by the P levels. The interaction genotypes vs. P levels were not significant for all traits. The coefficient of variation for the joint analysis varied from $5.78 \%$ (RD) to $20.86 \%$ (RV). The ratio $\mathrm{CVg} / \mathrm{CVe}$ presented values greater than one for all traits, except for $\mathrm{RD}, \mathrm{SA} 2, \mathrm{SA} 3$ and SDW,indicating that most traits could be used as an index for the genotype selection (Cruz et al., 2012).

The hybrids performed very differently comparing low-P and high (as shown in Table 3), most hybrids had their root system worse under low-P. The genotypes SC121, $1236020 \mathrm{e}$ 1167017 presented the lowest means comparing all hybrids, under both environments. These genotypes are considered neither efficient nor responsive to P since they performed poorly under low-P and did not improve their roots under high-P. On the other hand, several hybrids were superior to the check cultivars, with significant root growth. The hybrids 1G100, AG1060 e DKB540 performed very wellin both conditions. Other hybrids with an outperformance for RL and SA were AG 1040, AG 1080, AG 1090, As4615, AS 4625, AS 4639, DKB 550, DKB 590, MSK 326, and A9735R. All these hybrids outstood the check cultivars.

The PCA analysis allowed the clustering of contrasting sorghum hybrids based on root morphology and dry weight traits. The PC1 explained $48.7 \%$ and PC2 22\% of the variation in the sorghum genotypes grown under low-P (Figure 2A), while under high-P, PC1 explained 46.6\% and PC2 23.2\% of the variation (Figure 2B). For both low and high-P, the first principal component (PC1) had negative eigenvector coefficients for all traits, except for RD and RSR (Table 4).

In Figure 2, the red arrows indicate the correlation among the traits. The correlations were very similar in both P levels. SA was significantly correlated positively to RL under low-P ( $\mathrm{r}=0.96, \mathrm{p}<0.05)$ and under high- $\mathrm{P}$ $(\mathrm{r}=0.96, \mathrm{p}<0.05)$, and to SA2 under low-P $(\mathrm{r}=0.95, \mathrm{p}<0.05)$ and under high-P $(r=0.93, p<0.05)$. In addition, $S A 2$ was positively correlated with SA3 under low-P $(r=0.61$, $\mathrm{p}<0.05)$ and high- $\mathrm{P}(\mathrm{r}=0.76, \mathrm{p}<0.05)$ (see Figure $2 \mathrm{~A}$ and $2 \mathrm{~B}$ ). RD was negatively correlated to SA2 $(\mathrm{r}=-0.13, \mathrm{p}<0.05)$ and SA3 ( $\mathrm{r}=-0.05, \mathrm{p}<0.05)$. RSR obtained a low correlated with RL under low-P and high-P $(\mathrm{r}=0.38$ and $\mathrm{r}=0.34, \mathrm{p}<0.05)$, for $\mathrm{SA}(\mathrm{r}=0.37$ and $\mathrm{r}=0.32, \mathrm{p}<0.05)$, SA1 $(\mathrm{r}=0.34$ and $\mathrm{r}=0.48$, $\mathrm{p}<0.05)$.

Comparing the genotype position on the scatterplot (Figure 2), it was possible to observe that genotypes located in the right quadrant, 1167017 (38), SC121 (39), and 1236020 (37) had the lowest means for RL and SA, whereas genotypes AG1090 (14), MSK 326 (22), AG 1060 (12), AS 4639 (17), DKB 540 (18), DKB 590 (20) and 1G100 (4), located in the extreme part of the left quadrant, presented higher RL and SA. The clusters via UPGMA analysis (Figure 3) were analogous with the PCA (Figure 2), corroborating the information obtained a priori based on the identification of the groups in the quadrants.

UPGMA clustering analysis using euclidean distances generated different clusters, based on root morphology and dry weight data of sorghum hybrids grown in hydroponics with low-P (Figure 3A) and high-P (Figure 3B). The groups Q2 (green) and Q3 (yellow) presented nine genotypes each one (Figure 3A). The groups Q1 (red) and Q4 (blue) had twelve and ten genotypes, respectively (Figure 3B). The colors red (Q1) and blue (Q4) represented genotypes that presented higher means for RL and SA. On the other hand, the colors green (Q2) and yellow (Q3) indicated genotypes, which presented smaller RL and SA.

\section{Discussion}

The root system morphology and architecture traits determine the capacity of the plant to access P from the soil since its absorption occurs through diffusion and not by mass flow (Barber, 1995; Lynch, 2019). The diffusion

Table 2. Summary of the joint analysis of variance for 40 sorghum genotypes grown in nutrient solution with low and high $\mathrm{P}$.

\begin{tabular}{|c|c|c|c|c|c|c|c|c|c|c|c|}
\hline \multirow{2}{*}{ SV } & \multirow{2}{*}{ DF } & \multicolumn{10}{|c|}{ Mean square } \\
\hline & & $\mathbf{R L}$ & SA & RD & RV & SA1 & SA2 & SA3 & SDW & RDW & RSR \\
\hline Genotype (G) & 39 & $27862.74^{* *}$ & $2215.05^{* *}$ & $0.012^{* *}$ & $1.26^{* *}$ & $804.77^{* *}$ & $322.80^{* *}$ & $8.32^{* *}$ & $0.00013^{* *}$ & $0.00006^{*}$ & $0.22^{* *}$ \\
\hline P level (P) & 1 & $48426.83^{* *}$ & $1051.48^{*}$ & $0.059^{* *}$ & $0.014^{\mathrm{ns}}$ & $959.40^{* *}$ & $6.61^{\mathrm{ns}}$ & $1.14^{\mathrm{ns}}$ & $0.00028^{* *}$ & $0.00001^{\mathrm{ns}}$ & $0.40^{* *}$ \\
\hline $\mathrm{G} v s \mathrm{P}$ & 39 & $2390.89^{\text {ns }}$ & $247.52^{\text {ns }}$ & $0.0025^{\mathrm{ns}}$ & $0.19^{\text {ns }}$ & $61.36^{\mathrm{ns}}$ & $64.63^{\text {ns }}$ & $4.26^{\mathrm{ns}}$ & $0.00002^{\mathrm{ns}}$ & $0.00001^{\mathrm{ns}}$ & $0.03^{\text {ns }}$ \\
\hline Error & 158 & 3274.661 & 266.530 & 0.002 & 0.171 & 84.873 & 75.18 & 4.48 & 0.0000 & 0.0000 & 0.025 \\
\hline Mean & & 382.753 & 103.325 & 0.862 & 2.241 & 50.578 & 36.26 & 4.84 & 0.0281 & 0.0234 & 0.872 \\
\hline$h^{2}$ & & 0.88 & 0.51 & 0.17 & 0.45 & 0.57 & 0.52 & 0.41 & 0.6 & 0.6900 & 0.55 \\
\hline CVe (\%) & & 14.95 & 15.80 & 5.78 & 18.43 & 18.22 & 23.91 & 43.73 & 20.8171 & 15.5572 & 18.02 \\
\hline$C V g(\%)$ & & 16.73 & 17.44 & 4.64 & 19.05 & 21.66 & 17.72 & 16.53 & 14.1952 & 11.8110 & 20.86 \\
\hline CVg/CVe (\%) & & 1.12 & 1.10 & 0.80 & 1.03 & 1.19 & 0.74 & 0.38 & 0.6819 & 0.7592 & 1.16 \\
\hline
\end{tabular}

Source of variation (SV); ${ }^{*},{ }^{*}$, ns: significant at $1 \%$ and not significant by the test F. Degrees of freedom (DF); root length (RL - cm); root diameter (RD - mm); root volume $\left(\mathrm{RV}-\mathrm{cm}^{3}\right)$; total surface area $\left(\mathrm{SA}-\mathrm{cm}^{2}\right)$; surface area of roots with diameter between 0 and $1 \mathrm{~mm}\left(\mathrm{SA} 1-\mathrm{cm}^{2}\right)$; surface area of roots with diameter between 1 and $2 \mathrm{~mm}\left(\mathrm{SA} 2-\mathrm{cm}^{2}\right)$; surface area roots with diameter $>2 \mathrm{~mm}\left(\mathrm{SA} 3-\mathrm{cm}^{2}\right)$; root-to-shoot ratio (RSR-g); root dry weight (RDW); shoot dry weight (SDW); heritability $\left(\mathrm{h}^{2}\right)$; coefficient of variation $(\mathrm{CV})$. 

贷 穴 F

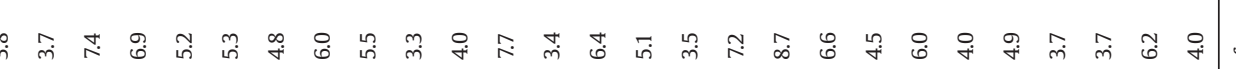

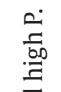

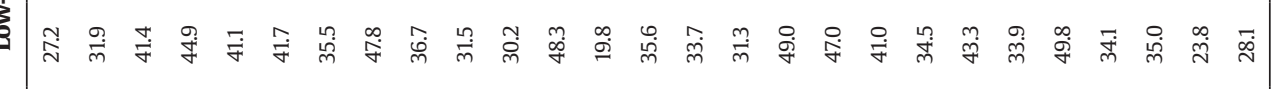

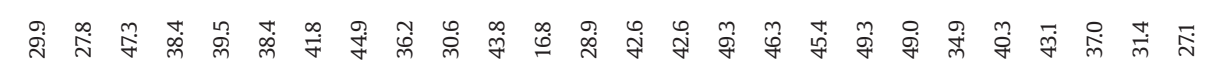

官 前

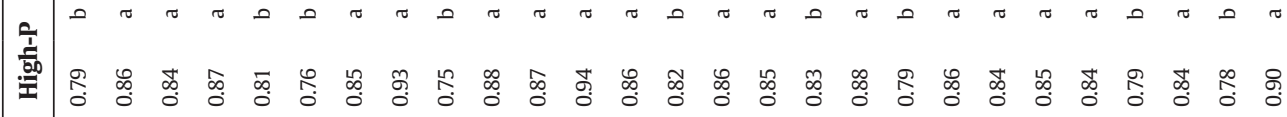
จิ

ஓ \& \& 产 范 $\nwarrow$

品 吊

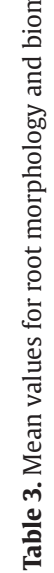

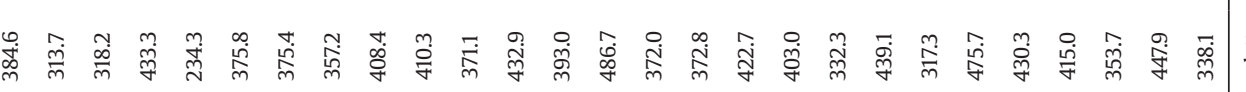

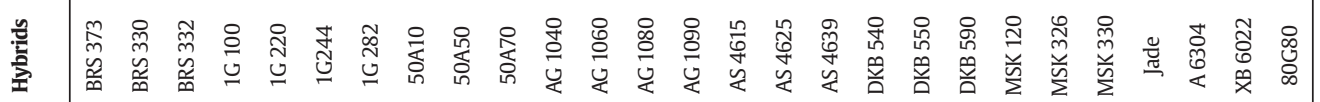

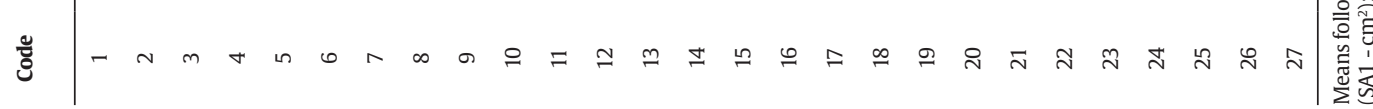




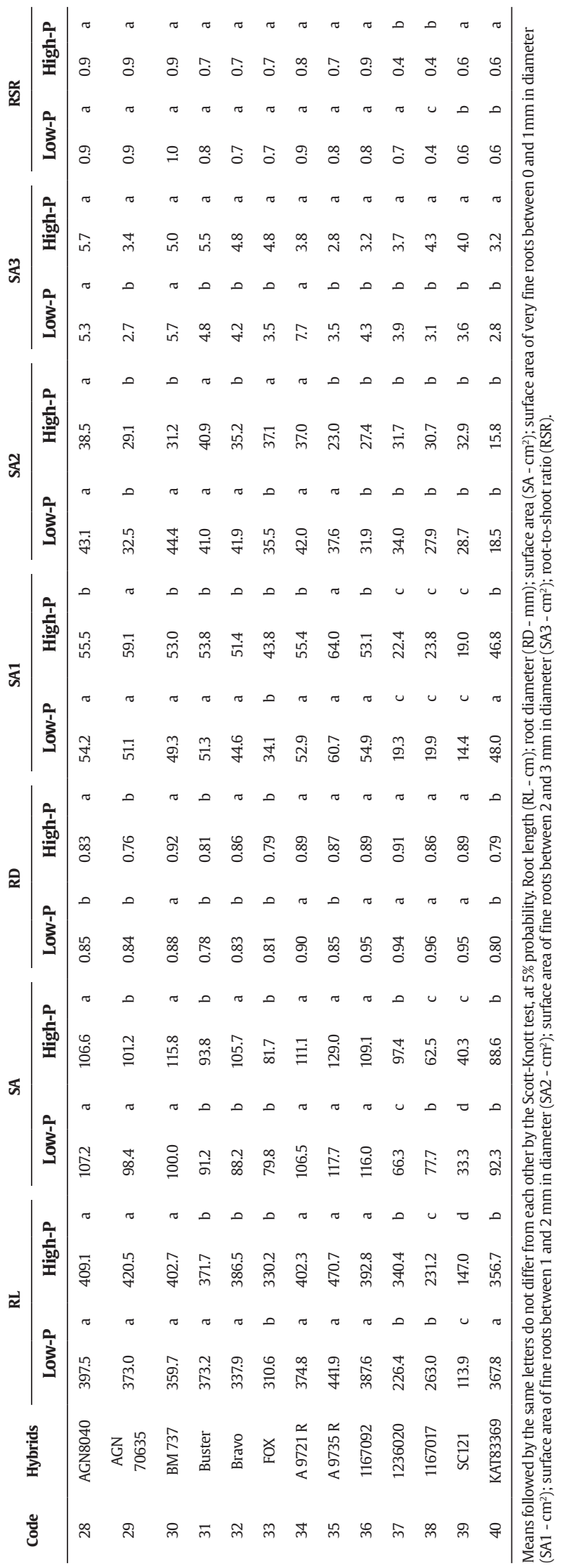


A

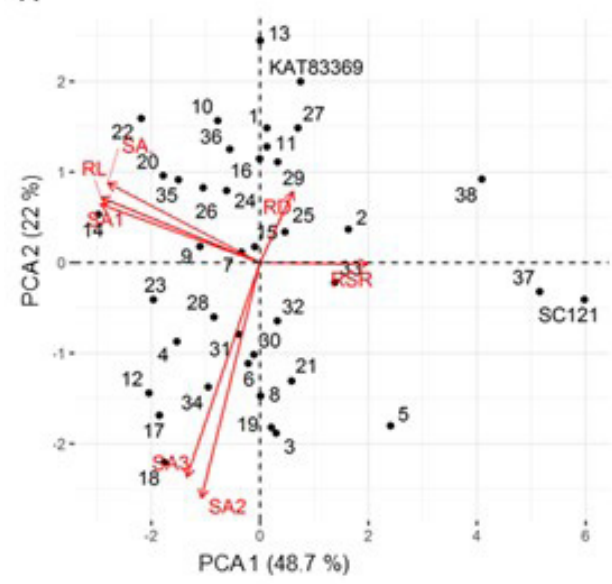

B

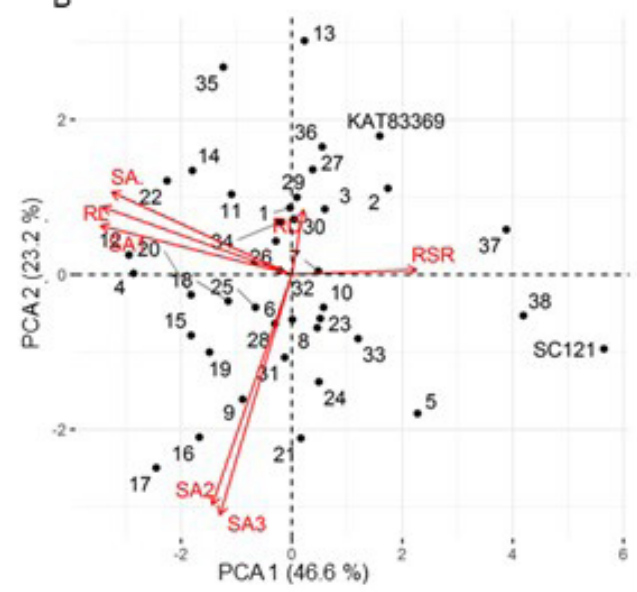

Figure 2. Principal component analysis for root and dry weight of sorghum plants grown under low (A) and high $P(B)$. Root length $(\mathrm{RL}-\mathrm{cm})$; root diameter $(\mathrm{RD}-\mathrm{mm})$; total surface area $\left(\mathrm{SA}-\mathrm{cm}^{2}\right)$; surface area of roots with diameter between 0 and $1 \mathrm{~mm}\left(\mathrm{SA} 1-\mathrm{cm}^{2}\right)$; surface area of roots with diameter between 1 and $2 \mathrm{~mm}\left(\mathrm{SA} 2-\mathrm{cm}^{2}\right)$; surface area roots with diameter $>2 \mathrm{~mm}\left(\mathrm{SA} 3-\mathrm{cm}^{2}\right)$; root-toshoot ratio (RSR); root dry weight (RDW - g); shoot dry weight (SDW - g).

Table 4. Principal component analysis for root traits.

\begin{tabular}{|c|c|c|c|c|c|c|}
\hline \multirow{2}{*}{ Traits } & \multicolumn{3}{|c|}{ Low-P } & \multicolumn{3}{|c|}{ High-P } \\
\hline & PC1 & PC2 & PC3 & PC1 & PC2 & PC3 \\
\hline Total root length $(\mathrm{cm})$ & -0.54 & 0.19 & 0.05 & -0.51 & 0.19 & 0.04 \\
\hline Total surface area $\left(\mathrm{cm}^{2}\right)$ & -0.49 & 0.23 & 0.26 & -0.49 & 0.23 & 0.28 \\
\hline Root diameter (mm) & 0.11 & 0.21 & 0.81 & 0.03 & 0.18 & 0.84 \\
\hline Root surface area $(0-1 \mathrm{~mm})\left(\mathrm{cm}^{2}\right)$ & -0.51 & 0.17 & 0.00 & -0.52 & 0.14 & -0.14 \\
\hline Root surface area $(1-2 \mathrm{~mm})\left(\mathrm{cm}^{2}\right)$ & -0.19 & -0.68 & 0.13 & -0.22 & -0.64 & 0.20 \\
\hline Root surface area $(>2 \mathrm{~mm})\left(\mathrm{cm}^{2}\right)$ & -0.24 & -0.62 & 0.24 & -0.20 & -0.67 & 0.12 \\
\hline Root-to-shoot ratio & 0.35 & -0.00 & 0.44 & 0.34 & 0.01 & 0.37 \\
\hline Explained variance (eigenvalue) & 1.84 & 1.24 & 1.07 & 1.80 & 1.27 & 1.08 \\
\hline Proportion of total variance (\%) & 48.68 & 22.05 & 16.61 & 46.69 & 23.17 & 16.85 \\
\hline Cumulative variance (\%) & 70.72 & 87.33 & 94.93 & 46.59 & 68.76 & 86.61 \\
\hline
\end{tabular}

Eigenvectors, eigenvalues and the cumulative proportion of total variance (\%) explained are shown for each principal component (PC).

requires proximity of the root with the nutrient in the soil, therefore, it is important to know the root traits that favor the P acquisition. Plants that present a shallower root system, greater root proliferation of adventitious roots reduced secondary root development and radial expansion, and greater root elongation, absorb P more efficiently (Lynch, 2011). Plants with these traits allow the root spread for soil regions richer in $\mathrm{P}$, reduce competition among roots of the same plant and explore the soil with a lower metabolic cost per unit length (Li et al., 2016; Lynch, 2019; Van Der Bom et al., 2020).

There was phenotypic variability among sorghum genotypes regarding root morphology and biomass traits under high and low P. The means of the evaluated traits for most genotypes was lower under low-P than under high-P, except for $1 \mathrm{G} 282,50 \mathrm{~A} 70$, MSK 330, Jade, and KAT83369 that presented higher means under low P. Selection under low-input conditions can hamper the optimal expression of many desired traits. The plant growth inhibition under P deficiency is due to reduced cell elongation and meristematic activity and is irreversible when P deficiency is maintained for many days, which will result in a lower grain yield (Reymond et al., 2006; Jain et al., 2007).

Many P-efficient genotypes have a root system comprising mainly very fine roots because this trait optimizes the root length to weight ratio. Grass species with fine and long roots acquire P more efficiently than those 
A

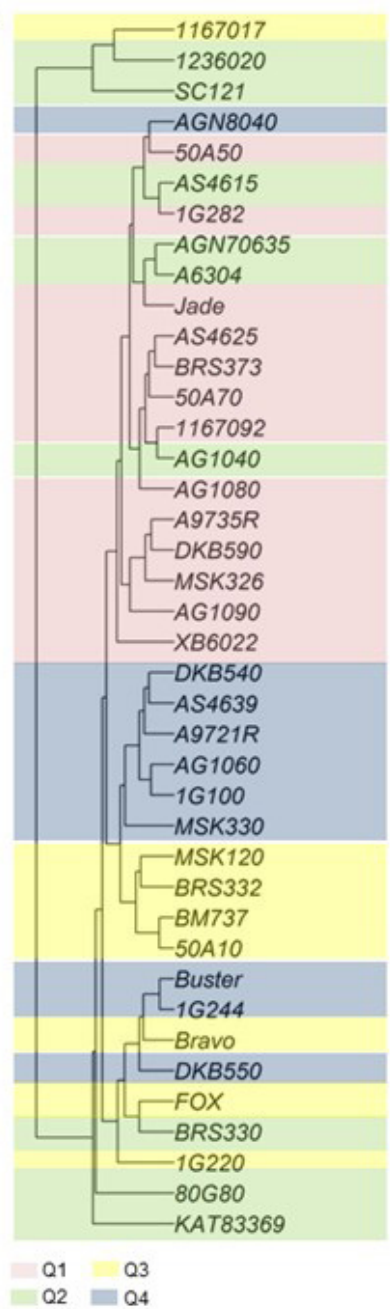

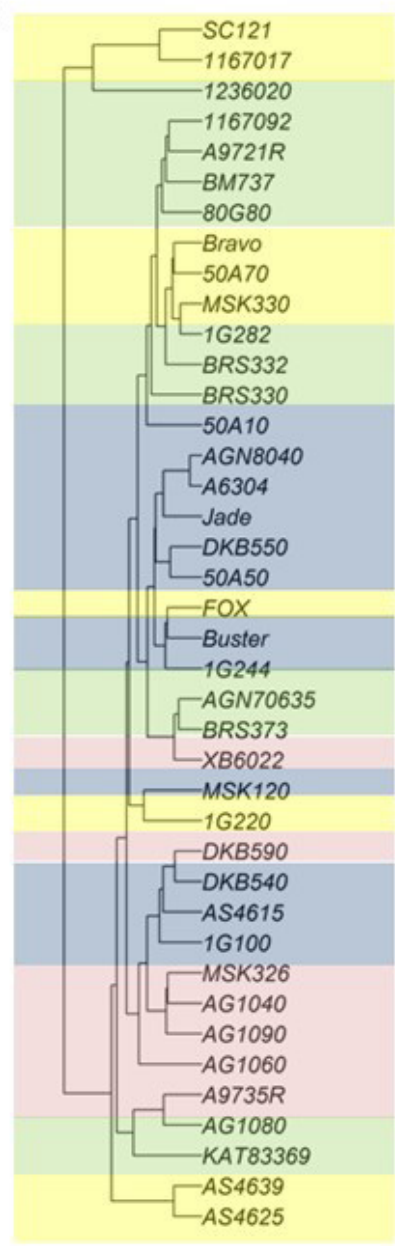

Figure 3. UPGMA dendogram showing the genetic relationships of 40 sorghum genotypes under low- $(A)$ and high-P(B). The background colors in the figure indicate the groups obtained via quadrants the analyses PCA. Red (Q1) and blue (Q4) colors represent genotypes likely P-efficient, once the root systems are characterized by higher averages for root surface area, a trait associated with P-efficiency. Green (Q2) and yellow (Q3) background indicates the hybrids likely P-inefficient, which presents a smaller root surface area.

plants with smaller and thicker roots (Hill et al., 2006). The sorghum genotypes 1G 100, AG 1040, AG 1060, AG 1090, AS 4615, AS 4625, AS 4639, DKB 540, DKB 550, DKB 590 , MSK 326, XB 6022, and A 9735 R showed the highest values for RL, SA, and SA1, which might indicate a better adaptation to low $\mathrm{P}$ availability. The carbon investment in a thinner root system allows plants to grow faster in a low P environment (Lynch, 2011).

Bernardino et al. (2020) found similar values for root and biomass traits while evaluating a Recombinant Inbred Line (RIL) population for a multi-trait quantitative trait loci (QTL) mapping to study the genetic architecture of $\mathrm{P}$ efficiency and to explore the importance of root traits in grain sorghum yield on a tropical low-P soil. The authors found values from $30 \mathrm{~cm}^{2}$ to $40 \mathrm{~cm}^{2}$ for SA and $S A 1$, respectively, indicating that the roots of the hybrids selected here presented superior means $\left(103.32 \mathrm{~cm}^{2}\right)$ and presented greater area for nutrient uptake compared to the inbred lines.

The PCA using root and dry weight traits showed a similar distribution for the sorghum genotypes along with the two major components (Figure 2). The PCA corroborated the diversity analysis. Under high-P it was observed four clusters. In Q2 and Q3, presented lower values for most traits (Figure 3), as an example of these groups the genotypes SC121, 1236020 e 1167017. In group Q1 and Q4, the genotypes 1G100, AG1060 e DKB540 presented higher values for all traits (Figure 3). These clusters corroborate to means and UPGMA dendrogram data.

The hybrids AG1090, MSK326, AG1060, 1G100, AS 4639, DKB 540, and DKB 590 stood out for root morphology and biomass traits under both P levels, based on the means (Table 3), the PCA clusters (Figure 2) and UPGMA dendrogram (Figure 3 ). These hybrids should be tested 
in the field to check their performance under low-P and studied for genes that control $P$ acquisition. All these hybrids performed very well under low-P, indicating they are $P$ efficient. Another advantage of these hybrids is that they are P-responsive once they improve their performance under high-P.

A finer root system increases the mining of the soil for diffusion-limited nutrients, such as P. However, there is a trade-off between decreased root diameter and enhanced $\mathrm{P}$ uptake, since beyond a given threshold there is a limitation on root penetration through the soil (Wu et al., 2016). Besides higher RL, the hybrids selected above presented higher total surface area and surface area of very fine roots.

Root phenotypes are the result of long and intensive selection for efficient and effective acquisition of soil resources (Lynch, 2019). The use of sorghum plants with improved $\mathrm{P}$ acquisition efficiency may represent a sustainable solution to increase crop yield in many agricultural systems.

\section{Acknowledgements}

The authors thank Gislene Rodrigues Braga Cristeli for technical assistance with growth chamber experiments. This research was supported by Embrapa.

\section{References}

BARBER, S.A., 1995. Soil nutrient bioavailability: a mechanistic approach. New York: John Wiley \& Sons. $414 \mathrm{p}$.

BARROS, V.A., CHANDNANI, R., SOUSA, S.M., MACIEL, L.S., TOKIZAWA, M., GUIMARÃES, C.T., MAGALHÃES, J.V. and KOCHIAN, L.V., 2020. Root adaptation via common genetic factors conditioning tolerance to multiple stresses for crops cultivated on acidic tropical soils. Frontiers in Plant Science, vol. 11, pp. 565339. http://dx.doi.org/10.3389/fpls.2020.565339 PMid:33281841.

BERNARDINO, K.C., PASTINA, M.M., MENEZES, C.B., SOUSA, S.M., MACIEL, L.S., CARVALHO-JR, G., GUIMARAES, C.T. and BARROS, B.A., 2020. The genetic architecture of phosphorus efficiency in sorghum involves pleiotropic QTL for root morphology and grain yield under low phosphorus availability in the soil. BMC Plant Biology, vol. 19, no. 1, pp. 19. http://dx.doi.org/10.1186/ s12870-019-1689-y PMid:30819116.

BERNARDINO, K.C., MENEZES, C.B., SOUSA, S.M., GUIMARAES, C.T., CARNEIRO, P.C.S., SCHAFFERT, R.E., KOCHAIN, L.V., HUFNAGEL, B., PASTINA, M.M. and MAGALHÃES, J.V., 2021. Association mapping and genomic selection for sorghum adaptation to tropical soils of Brazil in a sorghum multiparental random mating population. Theoretical and Applied Genetics, vol. 134, no. 1, pp. 295-312. http://dx.doi.org/10.1007/s00122-02003697-8 PMid:33052425.

CRUZ, C.D., 2013. GENES - a software package for analysis in experimental statistics and quantitative genetics. Acta Scientiarum. Agronomy, vol. 35, no. 3, pp. 271-276. http://dx.doi. org/10.4025/actasciagron.v35i3.21251.

CRUZ, C.D., REGAZZI, A.J., CARNEIRO, P.C.S., 2012. Modelos biométricos aplicados ao melhoramento genético. Viçosa: UFV, vol. 1.

FOOD AND AGRICULTURAL ORGANIZATION - FAO, 2020. FAOSTAT. Rome: FAO.
FREITAS, G.A., SOUSA, C.R., CAPONE, A., AFFÉRRI, F.S., MELO, A.V. and SILVA, R.R., 2012. Adubação orgânica no sulco de plantio e sua influência no desenvolvimento do sorgo. Journal of Biotechnology and Biodiversity, vol. 3, no. 1, pp. 61-67. http:// dx.doi.org/10.20873/jbb.uft.cemaf.v3n1.freitas.

HILL, J.O., SIMPSON, R.J., MOORE, A.D. and CHAPMAN, D.F., 2006. Morphology and response of roots of pasture species to phosphorus and nitrogen nutrition. Plant and Soil, vol. 286, no. 1, pp. 7-19. http://dx.doi.org/10.1007/s11104-006-0014-3.

HUFNAGEL, B., SOUSA, S.M., ASSIS, L., GUIMARÃES, C.T., LEISER, W., AZEVEDO, G.C., NEGRI, B., LARSON, B.G., SHAFF, J.E., PASTINA, M.M., BARROS, B.A., WELTZIEN, E., RATTUNDE, H.F.W., VIANA, J.H., CLARK, R.T., FALCÃO, A., GAFAZZI, R., GARCIA, A.A.F., SCHAFFERT, R.E., KOCHIAN, L.V. and MAGALHÃES, J.V., 2014. Duplicate and conquer: multiple homologs of phosphorusstarvation tolerance1 enhance phosphorus acquisition and sorghum performance on low-phosphorus soils. Plant Physiology, vol. 166, no. 2, pp. 659677. http://dx.doi.org/10.1104/pp.114.243949 PMid:25189534.

HUND, A., TRACHSEL, S. and STAMP, P., 2009. Growth of axile and lateral roots of maize: I development of a phenotyping platform. Plant and Soil, vol. 325, no. 1-2, pp. 335-348. http:// dx.doi.org/10.1007/s11104-009-9984-2.

JAIN, A., POLING, M.D., KARTHIKEYAN, A.S., BLAKESLEE, J.J., PEER, W.A., TITAPIWATANAKUN, B., MURPHY, A.S. and RAGHOTHAMA, K.G., 2007. Differential effects of sucrose and auxin on localized phosphate deficiency-induced modulation of different traits of root system architecture in Arabidopsis. Plant Physiology, vol. 144, no. 1, pp. 232-247. http://dx.doi.org/10.1104/pp.106.092130 PMid:17369438.

LI, X., ZENG, R. and LIAO, H., 2016. Improving crop nutrient efficiency through root architecture modifications. Journal of Integrative Plant Biology, vol. 58, no. 3, pp. 193-202. http:// dx.doi.org/10.1111/jipb.12434 PMid:26460087.

LÓPEZ-ARREDONDO, D.L., LEYVA-GONZÁLEZ, M.A., GONZÁLEZMORALES, S.I., LÓPEZ-BUCIO, J. and HERRERA-ESTRELLA, L., 2014. Phosphate nutrition: improving low-phosphate tolerance in crops. Annual Review of Plant Biology, vol. 65, no. 1, pp. 95123. http://dx.doi.org/10.1146/annurev-arplant-050213-035949 PMid:24579991.

LYNCH, J.P., 2011. Root phenes for enhanced soil exploration and phosphorus acquisition: tools for future crops. Plant Physiology, vol. 156, no. 3, pp. 1041-1049. PMid:21610180.

LYNCH, J.P., 2019. Root phenotypes for improved nutrient capture: an underexploited opportunity for global agriculture. The New Phytologist, vol. 223, no. 2, pp. 548-564. PMid:30746704.

MAGALHÃES, J.V., SOUSA, S.M., GUIMARÃES, C.T. and KOCHIAN, L.V., 2017. The role of root morphology and architecture in phosphorus acquisition: physiological, genetic, and molecular basis. In: M.A. HOSSAIN, T. KAMIYA, D. J. BURRITT, L.-S. P. TRAN and T. FUJIWARA, eds. Plant macronutrient use efficiency: molecular and genomic perspectives in crop plants. London: Elsevier, chap. 7, pp. 123-147. http://dx.doi.org/10.1016/B9780-12-811308-0.00007-7.

MAGNAVACA, R., GARDNER, C. and CLARK, R.B., 1987 [viewed 9 June 2021]. Inheritance of aluminum tolerance in maize. In: W.H. GABELMAN and B.C. LOUGHMAN, eds. Genetic aspects of plant mineral nutrition [online]. Dordrecht: Springer, pp. 201212. Available from: https://ainfo.cnptia.embrapa.br/digital/ bitstream/item/47190/1/Inheritance-luminum.pdf

NATIONAL INSTITUTES OF HEALTH - NIH, 2020 [viewed 5 October 2020]. ImageJ [online]. Available from: http://rsb.info.nih.gov/ij/

NOVAIS, R.F. and SMYTH, T.J., 1999. Fósforo em solo e planta em condições tropicais. Viçosa: Universidade Federal de Viçosa, 399 p. 
PARADIS, E. and SCHLIEP, K., 2019. ape 5.0: an environment for modern phylogenetics and evolutionary analyses in R. Bioinformatics, vol. 35, no. 3, pp. 526-528. PMid:30016406.

PARENTONI, S. and SOUZA-JUNIOR, C.L., 2008. Phosphorus acquisition and internal utilization efficiency in tropical maize genotypes. Pesquisa Agropecuária Brasileira, vol. 43, no. 7, pp. 893-901. http://dx.doi.org/10.1590/S0100-204X2008000700014.

R CORE TEAM, 2016. $R$ : a language and environment for statistical computing. Vienna: R Foundation for Statistical Computing.

REGENT INSTRUMENTS INC., 2020 [viewed 5 October 2020]. WinRHIZO [online]. Available from: http://www.regent.qc.ca/ products/rhizo/rhizo.html

REYMOND, M., SVISTOONOFF, S., LOUDET, O., NUSSAUME, L. and DESNOS, T., 2006. Identification of QTL controlling root growth response to phosphate starvation in Arabidopsis thaliana. Plant, Cell E'Environment, vol. 29, no. 1, pp. 115-125. PMid:17086758.

SCOTT, A. and KNOTT, M., 1974. Cluster-analysis method for grouping means in analysis of variance. Biometrics, vol. 30, no. 3, pp. 507-512. http://dx.doi.org/10.2307/2529204.

SOUSA, S.M., CLARK, R.T., MENDES, F.F., OLIVEIRA, A.C., VASCONCELOS, M.J.V., PARENTONI, S.N., KOCHIAN, L.V., GUIMARÃES, C.T. and MAGALHÃES, J.V., 2012. A role for root morphology and related candidate genes in $\mathrm{P}$ acquisition efficiency in maize. Functional Plant Biology, vol. 39, no. 11, pp. 925-935. http://dx.doi.org/10.1071/FP12022 PMid:32480842.

UNITED STATES DEPARTMENT OF AGRICULTURE - USDA [online], 2020a [viewed 5 October 2020]. Available from: http://www. fas.usda.gov/psdonline/psdHome.aspx

UNITED STATES DEPARTMENT OF AGRICULTURE - USDA, 2020b [viewed 5 October 2020]. RootReader2D [online]. Available from: http://www.plantmineralnutrition.net/rootreader.htm

VAN DER BOM, F.J.T., WILLIAMS, A. and BELL, M.J., 2020. Root architecture for improved resource capture: trade-offs in complex environments. Journal of Experimental Botany, vol. 71, no. 19, pp. 5752-5763. http://dx.doi.org/10.1093/jxb/eraa324 PMid:32667996.

VAN EEUWIJK, F., BUSTOS-KORTS, D., MILLET, E.J., BOER, M.P., KRUIJER, W., THOMPSON, A., MALOSETTI, M., IWATA, H., QUIROZ, R., KUPPE, C., MULLER, O., BLAZAKIS, K.N., YU, K., TARDIEU, F. and CHAPMAN, S.C., 2019. Modelling strategies for assessing and increasing the effectiveness of new phenotyping techniques in plant breeding. Plant Science, vol. 282, pp. 23-39. PMid:31003609.

WICKHAM, H., 2016. ggplot2: elegant graphics for data analysis. Berlin, Germany: Springer.

WELTZIEN, E., RATTUNDE, H., CLERGET, B., SIART, S., TOURE, A. and SAGNARD, F., 2006 [viewed 5 October 2020]. Sorghum diversity and adaptation to drought in West Africa. In: J. DEVRA, I. MAR and L. SEARS, eds. Enhancing the use of crop genetic diversity to manage abiotic stress in agricultural production systems: proceedings of a workshop [online]. Rome: IPGRI, pp. 31-38. Available from: https://agritrop. cirad.fr/539488/

WEN, Z., LI, H., SHEN, Q., TANG, X., XIONG, C., LI, H., PANG, J., RYAN, M.H., LAMBERS, H. and SHEN, J., 2019. Tradeoffs among root morphology, exudation and mycorrhizal symbioses for phosphorus-acquisition strategies of 16 crop species. The New Phytologist, vol. 223, no. 2, pp. 882-895. PMid:30932187.

WU, Q., PAGÈS, L. and WU, J., 2016. Relationships between root diameter, root length and root branching along lateral roots in adult, field-grown maize. Annali di Botanica, vol. 90, no. 3, pp. 117-379. PMid:26744490.

YU, G., SMITH, D.K., ZHU, H., GUAN, Y. and LAM, T.T.-Y., 2017. ggtree: an $r$ package for visualization and annotation of phylogenetic trees with their covariates and other associated data. Methods in Ecology and Evolution, vol. 8, no. 1, pp. 28-36. http://dx.doi. org/10.1111/2041-210X.12628. 